Session ETD-455

\title{
Collaboration between Industry and Higher Education
}

\author{
Joseph J. Cecere \\ Science, Engineering and Technology Department, \\ Penn State Harrisburg, Pennsylvania
}

\begin{abstract}
Over 2,000 commercial and industrial projects representing over a billion square feet of construction in the United States in federal, state, private and in other countries are in the process of incorporating building information modeling (BIM). The cost to build with BIM can be 25\% more depending on the involvement in design and construction variables, including the training. Since owners see a huge benefit, they are increasingly using BIM. Therefore, university programs must update their students in this technology.
\end{abstract}

This paper examines the factors that influence an owner's decision in using BIM. This includes enhancing the project's coordination, addressing conflicts that reduce change orders, improving communications, and establishing a cost budget that can be better administered.

The paper will also discuss the relationship between the BIM industry and university construction programs, especially Penn State Harrisburg. This relationship results with the students becoming more aware of BIM, its transformation and the opportunities for them. PSH partnering has resulted in an excellent relationship with BIM industry and PSH construction related programs in educating its students to this rapidly changing technology.

\section{Introduction}

\section{Building Information Modeling}

Building information modeling (BIM) began as a concept when MIT computer designers introduced the idea of modeling with the real world. With advances in computer hardware and software technology, design software developers produced 4-D computer-aided design (CAD) applications that correlated objects and properties. As contractors adopted computerized project management, scheduling, and digitized estimating software, design professionals made the move to incorporate CAD as the stranded programs became more advanced and less expensive. The ability to electronically transmit design files and contract documents was a major step for the design/construction industry and owner. This support projects and advanced information sharing that increase the use of this technology and managing the project cost.

Owners saw the benefit from BIM design and construction methods through reduced claims, 
lower administrative costs, reduced schedule and the model's valuable information on life-cycle costs. They also saw it as a new way of creating and leveraging digital models for the design/construction industry and operation of projects. It is a revolutionizing way how firms communicate, solve problems and achieve better outcomes. The McGraw-Hill Construction's Report "The Business Value of BIM: Getting Building Information Modeling (BIM) to the Bottom Line," examined the real business values that projects were experiencing:

- Over half of the design/construction industry were using BIM or BIM-related tools --

- Current BIM users of all skill levels expect to double their application of BIM on projects.

- Experienced users are leveraging their BIM capabilities to win new work over their competitors, and rate this as among the greatest current benefits of BIM.

The Construction Users Roundtable (CURT), an organization that includes over 50 of the largest corporations in the US, saw BIM has an alternative project delivery system to save billions of dollars in construction costs and add value and sustainability to capital facilities.

The General Services Administration (GSA) requires the use of BIM. The GSA cited the advantage of BIM implementation as the data generated by the model that contributes to special program validation, 4-D phasing, and improved energy and sustainability performance. As GSA pushes greater use of BIM technology and experiences its benefits of collaborative project management, they paved the way for the adoption of BIM as a their standard in the architectural, engineering, and construction arenas.

As, CAD software became more advanced and functional, designers integrated many data functions thus making true information modeling a reality. With object-oriented BIM or performance modeling virtual design and construction (VDC) software, designers quickly learned the benefits of fully integrated 5-D design systems Today's BIM suites have import/export file capabilities that allow data to be exchanged with structural design, HVAC, and lighting analysis software. A designer can easily investigate the effects of rotating or translating the footprint of a project on its site to determine the most energy-efficient placement in terms of heating, cooling, and lighting requirements. Similar methods may be used to determine placement with respect to environmental impact and storm water pollution prevention. With today's global economy, many design firms choose to outsource detailing and drafting tasks to overseas operations. With collaborative techniques and a single model file, drafters in Europe or India can be chugging away on details while the primary designers sleep in New York. This method can drastically reduce overall design schedule and cut costs significantly.

\section{Consorting with Industry and Penn State Harrisburg}

Again, educational programs must keep current in order to provide each student with the necessary information and skills to perform successfully in this chosen career. Yet this goal may prove difficult if the program is not striving to keep abreast of the changes and advancements 
being made, especially in the industrial world. The BIM industrial relationships that a program develops are a critical element to its success. Programs must strive to foster and strengthen relationships with these organizations that will not only benefit the program but also the organization. The BIM industry relationship with Penn State Harrisburg has developed into a tremendous relationship. The various activities are an excellent example of a win-win relationship for the future of both university programs and industries.

\section{Trade Associations}

The Mid-Atlantic BX (MABX) trade association provides access to a suite of technology-based information including BIM and business development solutions tailored specifically to construction industry. This central PA organization understands the importance of partnering with higher education to prepare their member's future employers. MABX offered a series of presentations on BIM to its members including an introduction to advance training. They partnered with Penn State Harrisburg in offering several presentations at the university. These allow their members to learn more about the college's construction programs while learning this technology. MABX invited students to participate in their events. Students learned about BIM and how they may use this resource in their future profession. This participation and interacting with professionals on exercises broaden the student BIM knowledge.

National Associated General Contractors of America (AGC), which is the largest contractor association in United States, is a leader in BIM technology. Their national BIM committee continues to provide webinars presentations, workshops and other information about new BIM process. AGC partners with higher education to promote BIM. University research proposals related to BIM has been initiated as well as allowing students to participate in their activities. PSH students have attended their regional and national conferences that conducted seminars on various BIM topics.

An example of this participation is the Maryland AGC chapter, which provides the PSH construction programs with links to webinar programs. Students are able to hear from leaders on this technology and how this is being incorporated their future profession. Several of the program instructors are invited to participate in BIM workshops as well as other functions. This also has the instructor not only keeping current but they interact with the contractors, designers, and owners.

\section{Software Vendors}

Software vendors offer universities significant discounts on their products. This allows universities such as PSH to purchase current software so the students are exposed these applications prior to future employment. BIM-related vendors such as AutoCAD and Microsoft hosted presentations to the program on this technology. The presentation also made the students aware of BIM, its future and opportunities. The students were also given the opportunity for

Proceedings of the 2020 Conference for Industry and Education Collaboration Copyright $@ 2020$, American Society for Engineering Education 
special software student purchases. The program felt that making the students aware of BIM provides an excellent foundation in this new technology.

Other agencies, like the state transportation agency. Penn DOT (Pennsylvania Department of Transportation), have their own similar software and offer the software and training to PSH students, which may be the future workforce. PennDOT also holds an annual convention that firms that deal with PennDOT participate in. This conference includes seminars, networking events, and an exhibit show. PennDOT invites a group of students and faculty at no cost to participate in this event. Again, PSH people have an excellent source to interact with firms that they will possibly be working with after graduation.

\section{Conclusion}

This collaboration between industry and Penn State Harrisburg demonstrates how successful this is. and they both help each other. Both groups realize the need to work together for the betterment of the students and the construction industry's future. Programs that develop and strengthen these relationships will not only benefit students but give them a better educational experience.

\section{References}

[1] Matthew Phair, "Virtual Design and Construction Goes Mainstream,” Building Design \& Construction, vol. 47, issue 9, 2016.

[2] McGraw-Hill, “Construction Report,” New York: McGraw-Hill, 2019.

[3] "Industry and Universities Collaboration: How Partnerships Drives Innovation,” 2019. [Online]. Available: https://venturewell.org/industry-and-university-collaboration/.

\section{Biographical Information}

JOSEPH J. CECERE, Ph.D., CPC, is an associate professor of Engineering and chair of the Civil Engineering as well as the Structural Design \& Construction Engineering Technology programs at Penn State Harrisburg. 